\title{
Impact of Climate Variability on Seed Yield of Onion in Mid Hills of Himachal Pradesh, India
}

\author{
Manohar Lal $^{1 *}$, H.S. Kanwar ${ }^{2}$, S.C. Verma ${ }^{3}$, Hukum Chand ${ }^{4}$ and Abhay Sharma ${ }^{4}$ \\ ${ }^{1}$ Department of Seed Science and Technology, ${ }^{2}$ Department of Vegetable Science, \\ ${ }^{3}$ Department of Entomology, ${ }^{4}$ Department of Environmental Science, Dr. YS Parmar \\ University of Horticulture and Forestry, Nauni, Solan (HP) - 173 230, India \\ *Corresponding author
}

K e y w o r d s
Climatic variability,
Onion (Allium cepa
L.), Seed yield

Keywords

Climatic variability, Onion (Allium cepa L.), Seed yield

Accepted:

Available Online:

10 February 2018

\section{A B S T R A C T}

Present investigation was conducted at Dr. YS Parmar University of Horticulture and Forestry, Nauni (HP) to study the effect of changing climatic conditions on seed yield of onion (Allium cepa L.) in mid hills of Himachal Pradesh. The meteorological data (30 years) and onion seed yield data (26 years) were collected; correlation and regression analysis between various weather parameters (temperature, rainfall and relative humidity) and onion seed productivity was done for productivity trend analysis. Weather based crop yield forecast model equation was developed and crop yield was predicted with maximum accuracy of 69 per cent. The trend analysis revealed that onion seed productivity over the last 26 years showed a fluctuating pattern with an overall decreasing trend at the rate of $2.58 \mathrm{~kg} \mathrm{ha}^{-1}$ per year. Climatic variability analysis indicated an increase in average temperature $\left(0.60^{\circ} \mathrm{C}\right.$ and $\left.0.46^{\circ} \mathrm{C}\right)$ and decrease in total rainfall $(57.02 \mathrm{~mm}$ and $183.14 \mathrm{~mm})$ during 1995-2004 (decade-1) and 2005-2014 (decade-2), respectively over the baseline (1985-1994). Whereas, relative humidity (RH) showed an increase of $0.03 \%$ during first decade and decrease of $3.39 \%$ during second decade over the baseline. Thus it can be concluded that changing climatic conditions in mid hills of Himachal Pradesh negatively affected the seed production of onion.

\section{Introduction}

Climate change has been become global brainstorming topic as well as major challenge to face especially in agriculture industry. In the next century, the global temperature could increase up to $4.8^{\circ} \mathrm{C}$ (IPCC, 2013) and if it rise by $2^{\circ} \mathrm{C}$ or more the production of the world's major crops such as wheat, rice and maize will be hampered (IPCC, 2014). Over the last century, the global mean surface temperature has increased by $0.6^{\circ} \mathrm{C}$ (Kumar et al., 2009). Though, the impact of climate change is not distributed evenly across the world (Chand, 2009). Globally, the impact of climate change on agriculture sector has become a matter of thinking in food security point of view because it can cause significant crop failures, shortage of yields, reduction in quality and increasing pest and disease problems (Ayyogari et al., 2014). 
Similarly, in North West Himalayas the climate is also changing with time and it has shown significant effects on the prevailing agriculture. The winter average temperature of the North West Himalayas followed an increasing trend (Dimri and Kumar, 2008). Cool season vegetable could be good indicator of climate change. Since onion is cool season vegetable crop and they can be more adversely affected by temperature extremes than some warm season crops (McKoewn et al., 2004). Therefore onion was chosen as an indicator crop. Among the various factors behind low seed productivity changing climatic conditions holds prime position. Non availability of the adequate quality seed is another factor which negatively affects the productivity and quality of seed also dependent on the prevailing weather.

There are different problems in North West Himalayan regions in onion seed production due to changing pattern in different climatic components such as extreme winters during vegetative growth or bulb development, high temperature during bolting and seed filling, rains during the flowering period, seed setting and maturity causes shattering and also, the climatic changes can enhance the changes in distribution and effectiveness of the pests and diseases (thrips, downy mildew, purple blotch) of the crop.

In onion seed production, it requires cool weather prior to and during early growth of seed stalk (Hazara and Som, 2009). The rising temperature during seed stalk growth period can affect it adversely and ultimately seed yield will be affected. Dry conditions reduce the occurrence of leaf diseases such as leaf blight (Msuya et al., 2005). Moreover, early rains during stalk development and flowering can harbour different diseases due to humid conditions. These all above mentioned factors reduces the seed quality as well as yield. Therefore the present study was planned to know the effect of different weather components on the seed yield of onion.

\section{Materials and Methods}

The present study was conducted during the year 2014-15 at Khaltoo Experimental Farm, Department of seed Science and Technology, Dr. YS Parmar University of Horticulture and Forestry, Nauni, Solan (Himachal Pradesh); located at an altitude of 1040 meters above mean sea level with latitude of $30^{\circ} 51^{\prime} 07.17^{\prime \prime} \mathrm{N}$ and longitude of $77^{\circ} 10^{\prime} 56.63 " \mathrm{E}$ in the midhill zone of Himachal Pradesh. The weather data (average monthly rainfall, maximum and temperature and relative humidity) for the period 1985-2014 was procured from Department of Environmental Science, Dr. YS Parmar University of Horticulture and Forestry, Nauni. Climate of the area is generally sub-temperate and semi-humid characterized by cold winters. The annual average maximum temperature varies from $17.72^{\circ} \mathrm{C}$ in January to $31.50^{\circ} \mathrm{C}$ in May, whereas the annual average minimum temperature ranges from $19.96^{\circ} \mathrm{C}$ in July to as low as $2.23^{\circ} \mathrm{C}$ in January. The average annual total rainfall recorded was $1156.19 \mathrm{~mm}$.

Variations in rainfall, maximum, minimum and average temperature and relative humidity were studied and analysed month wise as well as decadal for last three decades. The period 1985 to 1994 was taken as baseline and compared with decade 1995 to 2004 (decade1) and 2005 to 2014 (decade-2) for variations (increase or decrease) over baseline. Significant effect of dependent variables (weather parameters) on productivity was calculated using correlation analysis and backward regression. The final equation from regression analysis was used to predict the yield. Root mean square error was then computed to calculate error in the prediction by using formula: 
RMSE $=\sqrt{ } \Sigma(\text { Actual Yield-Predicted Yield })^{2} /$ Total number of observations

\section{Results and Discussion}

Monthly variations in maximum temperature $\left({ }^{\circ} \mathbf{C}\right)$

Data from the Table 1 shows prominent increase in maximum temperature over all the months except June during both the decades (1994-2004 and 2005-2014). In the present study highest increase of $2.39^{\circ} \mathrm{C}$ and $2.60^{\circ} \mathrm{C}$ in the month of December during both the decades 1995 to 2004 and 2005 to 2014 over the baseline. However, maximum variations of 11.97 per cent in maximum temperature were recorded in the month of January. This may be attributed to low precipitation during the winter months.

In Kullu Valley highest increase in average maximum temperature $\left(2.37^{\circ} \mathrm{C}\right)$ in the month of April during the period 1963-72 to 19952004 was recorded (Kumar et al., 2009). While, in another study March month showed highest increase during 1995-2004 and 20052014 over the base line (1985-1994) at Kullu and Shimla (Chand, 2016).

\section{Monthly variations in minimum temperature $\left({ }^{\circ} \mathrm{C}\right)$}

It is evident from the Table 1 that during 1995-2004 the monthly minimum temperature has been increased in all the months except March. During 2005 to 2014, the mean monthly minimum temperature increased by $0.29^{\circ} \mathrm{C}, 0.24^{\circ} \mathrm{C}$ and $0.15^{\circ} \mathrm{C}$, respectively in the months of February, May and July. During decade-1, maximum increase $\left(0.58^{\circ} \mathrm{C}\right)$ was observed in month of May and during decade2 it was maximum $\left(0.29^{\circ} \mathrm{C}\right)$ in the month of February over the baseline (1985 to 1994). This increase can also be attributed to the less rainfall in the respective months. The maximum variations of 61.95 per cent in minimum temperature were recorded during January month. In a study decrease in mean monthly minimum temperature over the base line (1985-1994) in most of the months during 2005-2014 at 2000-2500 m amsl (Shimla) was observed (Chand, 2016). Similarly in Kull valley highest increase in average monthly minimum temperature $\left(2.3^{\circ} \mathrm{C}\right)$ in the month of July during (1962-2004) was recorded (Kumar et al., 2009).

\section{Monthly variations in average temperature $\left({ }^{\circ} \mathrm{C}\right)$}

Perusal of data in Table 1 revealed that there is prominent increase in average monthly temperature in all the months except June during both the decades (1995 to 2004 and 2005 to 2014). The maximum increase of $1.28^{\circ} \mathrm{C}$ and $0.79^{\circ} \mathrm{C}$ was observed in the month of December during both the decade over the baseline. The less precipitation in the months of November and December might be the reason behind increase in average temperature. However, maximum variations $(14.96 \%)$ in the average monthly temperature were recorded in the month of January.

The findings are somewhat in agreement with a study in which an increase in average monthly temperature in all the months during 2001-2010 over the base line (1984-1990) in Sirmour (HP) was observed (Joshi, 2011). The increase in temperature during the winter months negatively affects the vernalization phenomenon and vernalization is important for bolting in onion.

\section{Decadal variations in maximum, minimum and average temperature $\left({ }^{\circ} \mathrm{C}\right)$}

The data presented in Table 2 revealed that decadal maximum temperature showed an increasing trend as $24.69^{\circ} \mathrm{C}<25.63^{\circ} \mathrm{C}<$ $25.93^{\circ} \mathrm{C}$ during the period 1985 to 1994,1995 
to 2004 and 2005 to 2014 , respectively. The maximum temperature showed an increase of $0.94^{\circ} \mathrm{C}$ and $1.24^{\circ} \mathrm{C}$ over the base line during the period of 1995 to 2004 and 2005 to 2014, respectively. The maximum temperature showed variations of 3.65 per cent during the last thirty years (1985-2014). In Kullu (HP) an increase of $1^{\circ} \mathrm{C}$ in average maximum temperature was recorded during 1990s compared to 1980s (Negi et al., 2012). In Himachal Pradesh, during 1951-2010 the annual mean maximum temperature was increased at the rate of $0.06^{\circ} \mathrm{C}$ (Rathore et al., 2013).

The data from the Table 2 showed that minimum temperature during the period 1985 to 1994,1995 to 2004 and 2005 to 2014 was $11.60^{\circ} \mathrm{C}, 11.85^{\circ} \mathrm{C}$ and $11.28^{\circ} \mathrm{C}$, respectively.

Present study revealed that decadal minimum temperature increased by $0.25^{\circ} \mathrm{C}$ during decade-1 (1995 to 2004), while it decreased by $0.32^{\circ} \mathrm{C}$ during decade-2 (2004 and 2005) over the base line.

The minimum temperature showed variations of 7.79 per cent over the period of thirty year. In another study, an increase in annual minimum $\left(2.75^{\circ} \mathrm{C}\right)$ during the period of 1963 2008 was recorded (Meena and Kumar, 2008). Whereas decreases in annual mean minimum temperature at the rate $0.01^{\circ} \mathrm{C}$ was observed in Himachal Pradesh during 1951-2010 (Rathore et al., 2013).

Perusal of data in Table 2 showed that decadal average temperature at selected study area was $18.14^{\circ} \mathrm{C}, 18.74^{\circ} \mathrm{C}$ and $18.61^{\circ} \mathrm{C}$, during the period of 1985 to 1994,1995 to 2004 and 2005 to 2014, respectively. It increased by $0.60^{\circ} \mathrm{C}$ and $0.46^{\circ} \mathrm{C}$ during decade- 1 and decade- 2 over the baseline. It showed variations of 3.68 per cent over the thirty years. The findings are somewhat in agreement with a study where an increasing trend during last three decades (1985-2014) at 2000-2500 m amsl (Shimla) with the variation of 5.59 per cent was recorded (Chand, 2016).

\section{Monthly variations in rainfall (mm)}

Scrutiny of data in Table 3 revealed that maximum decrease in total monthly rainfall i.e. $74.46 \mathrm{~mm}$ and $56.70 \mathrm{~mm}$ was observed in the month of July, whereas maximum increase $(68.94 \mathrm{~mm}$ and $23.10 \mathrm{~mm})$ was in the month June during both the decades (1995-2004 and 2005-2014) over the base line. However, maximum variations of 179.84 per cent in rainfall were observed during October month.

The results are in conformity with a report in which an increasing trend in June rainfall of Himachal Pradesh during 1951-2010 was found (Rathore et al., 2013).

From the present study it is cleared that there is decrease in rainfall in winters and spring season which adversely hamper the vegetative and reproductive growth of onion during seed production. In another report a decrease in rainfall during winters and spring seasons during 2001-2011 was recorded in sub temperate regions of Himachal Pradesh (Bhardwaj and Sharma, 2013).

Reduction in the rainfall during the seed fill months i.e. March and April may negatively affect the physiological development in seeds and also sometimes may cause the ovule abortion or unfilled grain.

\section{Decadal variations in rainfall $(\mathrm{mm})$}

The data presented in Table 4 revealed that decadal rainfall showed a decreasing trend as $1236.24 \mathrm{~mm}>1179.22 \mathrm{~mm}>1053.10 \mathrm{~mm}$ during the period 1985 to 1994,1995 to 2004 and 2005 to 2014, respectively. 
Table.1 Monthly decadal variations in maximum, minimum and average temperature $\left({ }^{\circ} \mathrm{C}\right)$

\begin{tabular}{|c|c|c|c|c|c|c|c|c|c|c|c|c|}
\hline \multirow[t]{3}{*}{ Time Period } & \multicolumn{12}{|c|}{ Month } \\
\hline & Jan & Feb & Mar & Apr & May & Jun & Jul & Aug & Sep & Oct & Nov & Dec \\
\hline & \multicolumn{12}{|c|}{ Maximum Temperature $\left({ }^{\circ} \mathbf{C}\right)$} \\
\hline $\begin{array}{l}\text { 1985-1994 } \\
\text { (Base Line) }\end{array}$ & 16.66 & 18.12 & 22.06 & 27.05 & 30.78 & 31.58 & 28.48 & 27.85 & 27.54 & 25.85 & 21.97 & 18.33 \\
\hline $\begin{array}{l}\text { 1995-2004 } \\
\text { (Decade-1) }\end{array}$ & 17.93 & 19.64 & 23.66 & 28.64 & 31.88 & 30.68 & 28.66 & 27.66 & 28.11 & 26.49 & 23.51 & 20.72 \\
\hline $\begin{array}{l}2005-2014 \\
\text { (Decade-2) }\end{array}$ & 18.58 & 19.37 & 24.57 & 28.39 & 31.84 & 31.56 & 28.55 & 28.21 & 28.1 & 27.17 & 23.91 & 20.93 \\
\hline Mean & 17.72 & 19.04 & 23.43 & 28.03 & 31.50 & 31.27 & 28.56 & 27.91 & 27.92 & 26.50 & 23.13 & 19.99 \\
\hline SD & 2.12 & 1.93 & 2.19 & 2.04 & 1.55 & 1.81 & 1.31 & 1.10 & 1.18 & 1.47 & 1.40 & 2.09 \\
\hline CV $(\%)$ & 11.97 & 10.11 & 9.33 & 7.27 & 4.92 & 5.78 & 4.59 & 3.94 & 4.22 & 5.55 & 6.05 & 10.47 \\
\hline \multicolumn{13}{|c|}{ Variations over the base line } \\
\hline Decade-1 & 1.27 & 1.52 & 1.60 & 1.59 & 1.10 & -0.90 & 0.18 & -0.19 & 0.57 & 0.64 & 1.54 & 2.39 \\
\hline Decade-2 & 1.92 & 1.25 & 2.51 & 1.34 & 1.06 & -0.02 & 0.07 & 0.36 & 0.56 & 1.32 & 1.94 & 2.60 \\
\hline Time Period & \multicolumn{12}{|c|}{ Minimum Temperature $\left({ }^{\circ} \mathbf{C}\right)$} \\
\hline $\begin{array}{l}\text { 1985-1994 } \\
\text { (Base Line) }\end{array}$ & 2.36 & 4.15 & 9.12 & 12.52 & 16.16 & 18.85 & 19.72 & 19.42 & 16.80 & 10.79 & 6.13 & 3.17 \\
\hline $\begin{array}{l}\text { 1995-2004 } \\
\text { (Decade-1) }\end{array}$ & 2.44 & 4.48 & 8.53 & 12.91 & 16.74 & 18.98 & 20.29 & 19.88 & 17.14 & 11.14 & 6.37 & 3.33 \\
\hline $\begin{array}{l}2005-2014 \\
\text { (Decade-2) } \\
\end{array}$ & 1.89 & 4.44 & 8.16 & 12.38 & 16.4 & 18.49 & 19.87 & 19.4 & 16.52 & 10.27 & 5.4 & 2.15 \\
\hline Mean & 2.23 & 4.36 & 8.60 & 12.60 & 16.43 & 18.77 & 19.96 & 19.57 & 16.82 & 10.73 & 5.97 & 2.88 \\
\hline SD & 1.38 & 1.46 & 2.27 & 1.62 & 1.58 & 1.42 & 1.27 & 1.39 & 1.52 & 1.53 & 1.44 & 1.26 \\
\hline CV (\%) & 61.95 & 33.50 & 26.40 & 12.85 & 9.62 & 7.58 & 6.34 & 7.10 & 9.02 & 14.29 & 24.11 & 43.53 \\
\hline \multicolumn{13}{|c|}{ Variations over the base line } \\
\hline Decade-1 & 0.08 & 0.33 & -0.59 & 0.39 & 0.58 & 0.13 & 0.57 & 0.46 & 0.34 & 0.35 & 0.24 & 0.16 \\
\hline Decade-2 & -0.47 & 0.29 & -0.96 & -0.14 & 0.24 & -0.36 & 0.15 & -0.02 & -0.28 & -0.52 & -0.73 & -1.02 \\
\hline Time Period & \multicolumn{12}{|c|}{ Average Temperature $\left({ }^{\circ} \mathbf{C}\right)$} \\
\hline \begin{tabular}{|l|l|}
$1985-1994$ \\
(Base Line) \\
\end{tabular} & 9.51 & 11.14 & 15.59 & 19.79 & 23.47 & 25.22 & 24.10 & 23.64 & 22.17 & 18.32 & 14.05 & 10.75 \\
\hline $\begin{array}{l}1995-2004 \\
\text { (Decade-1) } \\
\end{array}$ & 10.19 & 12.06 & 16.10 & 20.78 & 24.31 & 24.83 & 24.48 & 23.77 & 22.63 & 18.82 & 14.94 & 12.03 \\
\hline $\begin{array}{l}2005-2014 \\
\text { (Decade-2) }\end{array}$ & 10.24 & 11.91 & 16.37 & 20.39 & 24.12 & 25.03 & 24.21 & 23.81 & 22.31 & 18.72 & 14.66 & 11.54 \\
\hline Mean & 9.98 & 11.70 & 16.02 & 20.32 & 23.97 & 25.02 & 24.26 & 23.74 & 22.37 & 18.62 & 14.55 & 11.44 \\
\hline SD & 1.44 & 1.33 & 1.91 & 1.57 & 1.25 & 1.33 & 1.09 & 1.03 & 1.09 & 1.22 & 1.00 & 1.14 \\
\hline CV (\%) & 14.46 & 11.39 & 11.93 & 7.72 & 5.20 & 5.31 & 4.48 & 4.34 & 4.86 & 6.53 & 6.87 & 9.93 \\
\hline \multicolumn{13}{|c|}{ Variations over the base line } \\
\hline Decade-1 & 0.67 & 0.92 & 0.51 & 0.99 & 0.84 & -0.38 & 0.38 & 0.13 & 0.45 & 0.50 & 0.89 & 1.28 \\
\hline Decade-2 & 0.72 & 0.77 & 0.78 & 0.60 & 0.65 & -0.19 & 0.11 & 0.17 & 0.14 & 0.40 & 0.60 & 0.79 \\
\hline
\end{tabular}

Table. 2 Decadal variations in maximum, minimum and average temperature $\left({ }^{\circ} \mathrm{C}\right)$

\begin{tabular}{|l|c|c|c|}
\hline \multicolumn{1}{|c|}{ Time Period } & $\begin{array}{l}\text { Maximum } \\
\text { Temperature }\left({ }^{\circ} \mathbf{C}\right)\end{array}$ & $\begin{array}{l}\text { Minimum } \\
\text { Temperature }\left({ }^{\circ} \mathbf{C}\right)\end{array}$ & $\begin{array}{l}\text { Average } \\
\text { Temperature }\left({ }^{\circ} \mathbf{C}\right)\end{array}$ \\
\hline $\mathbf{1 9 8 5 - 1 9 9 4}$ (Base Line) & 24.69 & 11.60 & 18.14 \\
\hline $\mathbf{1 9 9 5 - 2 0 0 4}$ (Decade-1) & 25.63 & 11.85 & 18.74 \\
\hline $\mathbf{2 0 0 5 - 2 0 1 4}$ (Decade-2) & 25.93 & 11.28 & 18.61 \\
\hline Mean & $\mathbf{2 5 . 4 2}$ & $\mathbf{1 1 . 5 8}$ & $\mathbf{1 8 . 5 0}$ \\
\hline SD & 0.93 & 0.90 & 0.68 \\
\hline CV $(\%)$ & 3.65 & 7.79 & 3.68 \\
\hline Variations over the base line & & & 0.60 \\
\hline Decade-1 & 0.94 & 0.25 & 0.46 \\
\hline Decade-2 & 1.24 & -0.32 & \\
\hline
\end{tabular}


Table.3 Month wise decadal variations in total rainfall (mm)

\begin{tabular}{|c|c|c|c|c|c|c|c|c|c|c|c|c|}
\hline \multirow[t]{2}{*}{ Time Period } & \multicolumn{12}{|c|}{ Month } \\
\hline & Jan & Feb & Mar & Apr & May & Jun & Jul & Aug & Sep & Oct & Nov & Dec \\
\hline 1985-1994 (Base Line) & 60.33 & 67.65 & 72.34 & 31.18 & 80.29 & 100.46 & 318.30 & 267.62 & 133.48 & 27.62 & 13.75 & 63.22 \\
\hline 1995-2004 (Decade-1) & 60.91 & 66.2 & 60.83 & 50.08 & 65.41 & 169.4 & 243.84 & 266.11 & 127.84 & 45.72 & 7.26 & 15.62 \\
\hline 2005-2014 (Decade-2) & 47.84 & 89.49 & 62.92 & 25.59 & 41.55 & 123.56 & 261.6 & 182.46 & 170.63 & 14.75 & 6.94 & 25.77 \\
\hline Mean & 56.36 & 74.45 & 65.36 & 35.62 & 62.42 & 131.14 & 274.58 & 238.73 & 143.98 & 29.36 & 9.32 & 34.87 \\
\hline SD & 39.37 & 56.29 & 50.01 & 30.30 & 62.34 & 83.92 & 198.32 & 125.23 & 110.85 & 52.81 & 16.63 & 47.00 \\
\hline CV (\%) & 69.85 & 75.62 & 76.51 & 85.06 & 99.87 & 63.99 & 72.23 & 52.46 & 76.99 & 179.84 & 178.47 & 134.79 \\
\hline \multicolumn{13}{|c|}{ Variations over the base line } \\
\hline Decade-1 & 0.58 & -1.45 & -11.51 & 18.90 & -14.88 & 68.94 & -74.46 & -1.51 & -5.64 & 18.10 & -6.49 & -47.60 \\
\hline Decade-2 & -12.49 & 21.84 & -9.42 & -5.59 & -38.74 & 23.10 & -56.70 & -85.16 & 37.15 & -12.87 & -6.81 & -37.45 \\
\hline
\end{tabular}

Table.4 Decadal variations in total rainfall $(\mathrm{mm})$

\begin{tabular}{|l|c|}
\hline Time Period & Rainfall (mm) \\
\hline 1985-1994 (Base Line) & 1236.24 \\
\hline 1995-2004 (Decade-1) & 1179.22 \\
\hline 2005-2014 (Decade-2) & 1053.10 \\
\hline Mean & $\mathbf{1 1 5 6 . 1 9}$ \\
\hline SD & 338.02 \\
\hline CV (\%) & 29.24 \\
\hline Variations over the base line \\
\hline Decade-1 & -57.02 \\
\hline Decade-2 & -183.14 \\
\hline
\end{tabular}

Table.5 Month wise decadal variations in relative humidity (\%)

\begin{tabular}{|c|c|c|c|c|c|c|c|c|c|c|c|c|}
\hline \multirow[t]{2}{*}{ Time Period } & \multicolumn{12}{|c|}{ Month } \\
\hline & Jan & Feb & Mar & Apr & May & Jun & Jul & Aug & Sep & Oct & Nov & Dec \\
\hline 1985-1994 (Base Line) & 61.25 & 59.99 & 55.83 & 48.62 & 50.08 & 60.85 & 79.95 & 83.51 & 75.19 & 59.06 & 58.69 & 59.93 \\
\hline 1995-2004 (Decade-1) & 60.28 & 61.58 & 52.36 & 48.56 & 45.28 & 64.29 & 79.61 & 83.00 & 76.45 & 63.02 & 61.52 & 57.37 \\
\hline 2005-2014 (Decade-2) & 56.80 & 58.35 & 50.90 & 44.90 & 46.50 & 54.35 & 76.40 & 79.80 & 74.35 & 60.00 & 52.75 & 52.35 \\
\hline Mean & 59.44 & 59.97 & 53.03 & 47.36 & 47.29 & 59.83 & 78.65 & 82.10 & 75.33 & 60.69 & 57.65 & 56.55 \\
\hline SD & 7.01 & 9.58 & 8.23 & 9.59 & 9.08 & 11.51 & 5.13 & 4.04 & 7.10 & 6.64 & 8.96 & 7.41 \\
\hline CV $(\%)$ & 11.80 & 15.98 & 15.51 & 20.24 & 19.20 & 19.24 & 6.52 & 4.93 & 9.43 & 10.93 & 15.55 & 13.10 \\
\hline \multicolumn{13}{|c|}{ Variations over the base line } \\
\hline Decade-1 & -0.97 & 1.59 & -3.47 & -0.06 & -4.80 & 3.44 & -0.34 & -0.51 & 1.26 & 3.96 & 2.83 & -2.56 \\
\hline Decade-2 & -4.45 & -1.64 & -4.93 & -3.72 & -3.58 & -6.50 & -3.55 & -3.71 & -0.84 & 0.94 & -5.94 & -7.58 \\
\hline
\end{tabular}

Table.6 Decadal variations in relative humidity (\%)

\begin{tabular}{|l|c|}
\hline Time Period & Relative Humidity (\%) \\
\hline 1985-1994 (Base Line) & 62.75 \\
\hline 1995-2004 (Decade-1) & 62.78 \\
\hline 2005-2014 (Decade-2) & 58.95 \\
\hline Mean & $\mathbf{6 1 . 4 9}$ \\
\hline SD & 3.90 \\
\hline CV (\%) & 6.35 \\
\hline Variations over the base line \\
\hline Decade-1 \\
\hline Decade-2
\end{tabular}


Table.7 Correlation analysis between onion seed productivity and weather parameters

\begin{tabular}{|c|c|}
\hline Weather Parameters & Productivity \\
\hline \multicolumn{2}{|l|}{ Maximum Temperature } \\
\hline Maximum Temperature of cropping season $\left({ }^{\circ} \mathrm{C}\right)$ & -0.1718 \\
\hline Maximum Temperature October $\left({ }^{\circ} \mathrm{C}\right)$ & $-0.4213^{*}$ \\
\hline Maximum Temperature November $\left({ }^{\circ} \mathrm{C}\right)$ & -0.1263 \\
\hline Maximum Temperature December $\left({ }^{\circ} \mathrm{C}\right)$ & -0.0570 \\
\hline Maximum Temperature January $\left({ }^{\circ} \mathrm{C}\right)$ & 0.1366 \\
\hline Maximum Temperature February $\left({ }^{\circ} \mathrm{C}\right)$ & -0.2274 \\
\hline Maximum Temperature March $\left({ }^{\circ} \mathrm{C}\right)$ & -0.3050 \\
\hline Maximum Temperature April $\left({ }^{\circ} \mathrm{C}\right)$ & -0.1316 \\
\hline Maximum Temperature May $\left({ }^{\circ} \mathrm{C}\right)$ & 0.2699 \\
\hline \multicolumn{2}{|l|}{ Minimum Temperature } \\
\hline Minimum Temperature of cropping season $\left({ }^{\circ} \mathrm{C}\right)$ & 0.1523 \\
\hline Minimum Temperature October $\left({ }^{\circ} \mathrm{C}\right)$ & -0.0043 \\
\hline Minimum Temperature November $\left({ }^{\circ} \mathrm{C}\right)$ & 0.3780 \\
\hline Minimum Temperature December $\left({ }^{\circ} \mathrm{C}\right)$ & 0.2100 \\
\hline Minimum Temperature January $\left({ }^{\circ} \mathrm{C}\right)$ & 0.1954 \\
\hline Minimum Temperature February $\left({ }^{\circ} \mathrm{C}\right)$ & 0.3210 \\
\hline Minimum Temperature March $\left({ }^{\circ} \mathrm{C}\right)$ & -0.1088 \\
\hline Minimum Temperature April $\left({ }^{\circ} \mathrm{C}\right)$ & -0.3066 \\
\hline Minimum Temperature May $\left({ }^{\circ} \mathrm{C}\right)$ & 0.0908 \\
\hline \multicolumn{2}{|l|}{ Rainfall } \\
\hline Rainfall of cropping season(mm) & 0.2318 \\
\hline Rainfall October (mm) & -0.0358 \\
\hline Rainfall November (mm) & $0.4351 *$ \\
\hline Rainfall December (mm) & -0.1397 \\
\hline Rainfall January (mm) & -0.2859 \\
\hline Rainfall February (mm) & $0.3906^{*}$ \\
\hline Rainfall March (mm) & $0.4299 *$ \\
\hline Rainfall April (mm) & 0.2252 \\
\hline Rainfall May (mm) & -0.2418 \\
\hline \multicolumn{2}{|l|}{ Relative Humidity } \\
\hline Relative Humidity of cropping season (\%) & $0.6469 *$ \\
\hline Relative Humidity October (\%) & 0.1993 \\
\hline Relative Humidity November (\%) & 0.2711 \\
\hline Relative Humidity December (\%) & 0.3482 \\
\hline Relative Humidity January (\%) & 0.0268 \\
\hline Relative Humidity February (\%) & $0.6764 *$ \\
\hline Relative Humidity March (\%) & $0.5117 *$ \\
\hline Relative Humidity April (\%) & $0.4294^{*}$ \\
\hline Relative Humidity May (\%) & 0.1512 \\
\hline
\end{tabular}

Table.8 Weather based yield forecast model equation

\begin{tabular}{|c|c|c|c|}
\hline Model Equation & $\mathbf{R}^{2}$ & RMSE & Std. Error of Estimates \\
\hline $\begin{array}{l}\text { Yield }=276.18+\left(91.45 \times X_{22}\right)+\left(-12.48 \times X_{31}\right)+\left(44.96 \times X_{20}\right) \\
+\left(1.07 \times X_{8}\right)\end{array}$ & 0.69 & 61.14 & 68.03 \\
\hline
\end{tabular}


Fig.1 Predicted and trends of actual onion seed yield over the period 26 years

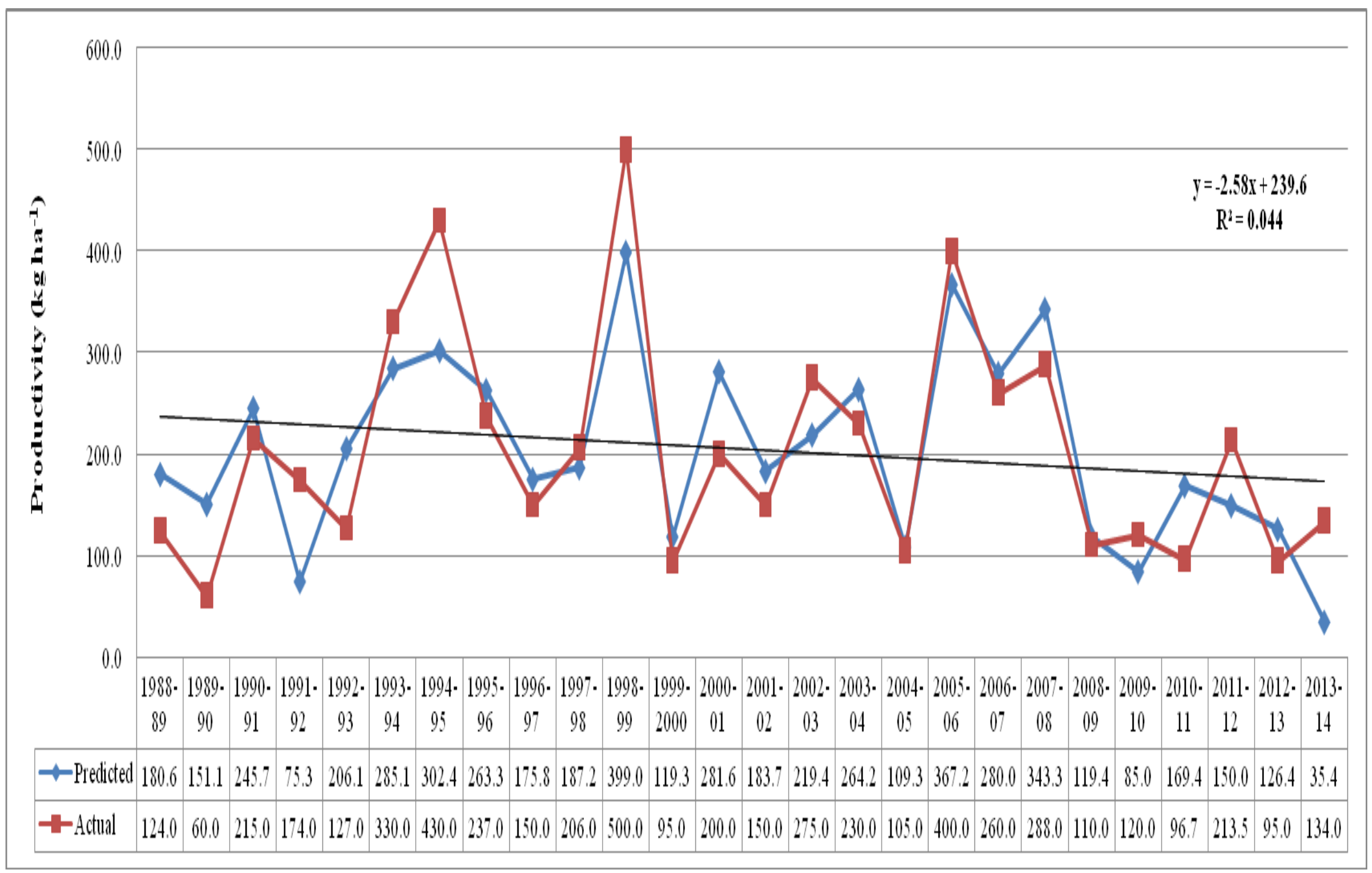


During the period 1995 to 2004, the mean rainfall decreased by $57.02 \mathrm{~mm}$ and during 2005 to 2014 it decreased by $183.14 \mathrm{~mm}$ over the baseline. It showed a variation of 29.24 per cent during last thirty years. Reduction in decadal rainfall could be attributed to decrease in annual rainfall over the years. There was a prominent decrease in rains in all the months except June. Present findings are in conformity with a study in which a decrease in rainfall in Kullu (1500-2000 m amsl) was recorded during two decades (1995-2014) over the base line (1985-1994) (Chand, 2016), but contradicting another finding which reported an increased per annum rainfall $(5.22 \mathrm{~cm})$ during $1995-2004$ as compared to 1963-72 in Kullu valley (Kumar et al., 2009).

\section{Monthly variations in relative humidity (RH) (\%)}

Data presented in Table 5 revealed that maximum increase in mean monthly $\mathrm{RH}$ i.e. $3.96 \%$ and $0.94 \%$ was observed in the month of October which during both the decades over the base line. However, maximum variations of 20.24 per cent in $\mathrm{RH}$ were observed during April month. In a study an increasing trends in average $\mathrm{RH}$ for the months of April to June was observed (Kumar et al., 2009). Reduction in RH in most of the months may be attributed to the reduced rainfall over the years.

\section{Decadal variations in relative humidity $R H$ $(\%)$}

The perusal of data presented in the Table 6 revealed that decadal $\mathrm{RH}$ during the period 1985 to 1994,1995 to 2004 and 2005 to 2014 was $62.75 \%, 62.78 \%$ and $58.95 \%$, respectively. The decadal $\mathrm{RH}$ increased by $0.03 \%$ during decade-1 (1995 to 2004), while it was decreased by $3.79 \%$ during decade- 2 (2005 to 2014) over the base line (1985 to
1994). The less RH may be due to reduction in precipitation and increasing trend of temperature. The maximum variations of 6.35 per cent in $\mathrm{RH}$ were observed during last thirty years.

\section{Correlation and regression analysis of onion seed productivity with weather parameters}

In the present study a significant (significant at $95 \%$ level of significance) positive correlation was observed between onion seed productivity and relative humidity for February $\left(r=0.6764^{*}\right)$, relative humidity for cropping season $(\mathrm{r}=0.6469 *)$, relative humidity for March $\left(\mathrm{r}=0.5117^{*}\right)$, rainfall for November $\left(r=0.4351^{*}\right)$, rainfall for March $(r$ $\left.=0.4299^{*}\right)$, relative humidity for April $(\mathrm{r}=$ $0.4294 *)$ and rainfall for February ( $\mathrm{r}=$ $\left.0.3906^{*}\right)$. Whereas, a significant negative correlation of onion seed productivity was observed with maximum temperature for October $(r=-0.4213 *)$. Negative correlation signifies that the increase in any of these parameters may cause reduction in onion seed productivity whereas positive correlation indicated that increase in any of these parameters will enhance the productivity.

Onion seed productivity was regressed with maximum temperature, minimum temperature, rainfall and relative humidity which predicted the onion seed productivity based upon regression equation developed for the selected area (Dr. YS Parmar University of Horticulture and Forestry, Nauni, Solan (HP)). The equation has been presented in the Table 8 and can be used as pre-harvest seed yield forecast model for onion crop. The regression equation is composed of minimum temperature of February, relative humidity of March, minimum temperature of December and rainfall of April which were positively correlated (Table 7). The regression equation was used to predict the onion seed yield for 
26 years and which was compared with the actual yield. By developing yield forecast model equation crop yield was predicted with an accuracy of $69 \%$. The predicted and actual yield showed nearly similar trends which have been depicted in the figure 1 . The onion seed productivity over the last 26 years showed a fluctuating pattern with an overall decreasing trend at the rate of $2.58 \mathrm{~kg} \mathrm{ha}^{-1}$ per year. Whereas, overall decrease in onion seed productivity in 26 years observed was 67.08 $\mathrm{kg} \mathrm{ha}^{-1}$. The model equation was validated using root mean square error (RMSE) which was $61.14 \mathrm{~kg} \mathrm{ha}^{-1}$. Standard error of estimates for model equation was 68.03.

The fluctuations in the final seed yield of the onion were due to the variations in the climatic components. The increase in the monthly average temperature of the seed production months (October to May) and reduction in rainfall especially during vegetative and reproductive growth of the onion plant would have reduced the seed yield. High temperature stress significantly reduced both grain and biomass yields (Amita et al., 2015). The present findings are in agreement with a report where reduction in seed yield of cabbage var. Golden Acre was recorded between the period of 1981- 2004 (Chand, 2016).

Thus from the present study it can be concluded that changing climatic conditions in mid hills of Himachal Pradesh negatively affected the seed production of onion and some agro techniques such as planting dates, planting geometries, mulches etc. need to be standardized.

\section{Acknowledgments}

I would like to acknowledge Ministry of Social Justice and Empowerment, Govt. Of India for financial assistance during the research programme.

\section{References}

Ayyogari, K., Sidhya, P. and Pandit. M.K. 2014. Impact of Climate Change on Vegetable Cultivation - A Review. Inter. J. Agric. Environ. Biotech. 7(1): 145-155.

Bhardwaj, S.K. and Sharma, S.D. 2013. Horticulture crop production in North Western Himalayas under changing climate scenario. Sci. Park. Res. J., 8(1): 1-7.

Chand, H. 2016. Assessment of apple crop vulnerability to climate change in Himachal Pradesh. Ph.D. Thesis. Department of Environmental Science, Dr. YS Parmar University of Horticulture and Forestry Solan (Nauni), Himachal Pradesh, India.

Dimri, A.P. and Kumar, A. 2008. Climatic variability of weather parameters over the western Himalayas: a case study, In: Proceeding of National Snow Science Workshop, 11-12 January 2008 [Satyawali, P.K and Ganju, A. (eds.)]. Chandigarh, India. Pp. 167-173.

Hazara, P. and Som, M.G. 2009. Vegetable Seed Production and Hybrid Technology. Kalayani Publisher, Ludhiana. 408p.

IPCC. 2013. Summary for the policy makers, In: Climate Change 2013. Physical Science Basis: Contribution of Working Group I to the fifth assessment Report of the Intergovernmental Panel on Climate Change. Cambridge University Press, Cambridge, UK and New York, USA.

IPCC. 2014. IPCC Fifth Assessment Report: Climate Change 2014. Geneva, Switzerland, Intergovernmental Panel on Climate Change.

Joshi, R. 2011. Studies on vulnerability of agro-forestry resources to climate change and its impact on farmers' economy in mid hills of western 
Himalayas. M.Sc. Thesis. Dr. YS Parmar University of Horticulture and Forestry, Nauni, Solan (HP), India.

Kumar, P.R., Yadav, S.K., Sharma, S.R., Lal, S.K. and Jha, D.N. 2009. Imapact of climate change on seed production of cabbage in North Western Himalayas. World. J. Agric. Sci., 5(1): 18-26.

McKoewn, A.W., Warland, J. and McDonald, M.R. 2004. Cool season crop production trends: a possible signal for global warming. Acta. Horti. 638: 241248.

Meena, R.P. and Kumar, P.R. 2008. Making an opportunity in changing climate scenario: a case of Kullu and Lahaul valley. Low External Input and Sustainable Agriculture, India 10(4): 31-32.

Msuya, D.G., Reuben, S.O.W.M., Mbilinyi, L.B., Maerere, A.P., Msogoya, T.,
Mulungu, L.S. and Misangu, R.N. 2005. Evaluation of field performance and storage of some tropical short-day onion (Allium cepa L.) cultivars. Worl. Afric. J. Ecol., 8: 10-18.

Negi, G.C.S., Samal, P.K., Kuniyal, J.C., Kothyari, B.P., Sharma, R.K. and Dhyani, P.P. 2012. Impact of climate change on the western Himalayan mountain ecosystem: An overview. Tropic. Ecol., 53(3): 345-356.

Raj, A., Chakrabarti, B., Pathak, H., Singh, S.D. and Pratap, D. 2015. Impact of elevated temperature on iron and zinc uptake in rice crop. Inter. J. Agric. Environ. Biotech, 8(3): 691-697.

Rathore, L.S., Attri, S.D. and Jaswal, A.K. 2013. State level climate change trends in India, Meteorological Monograph No. ESSO/IMD/Education Multimedia Research Centre/02/2013.

\section{How to cite this article:}

Manohar Lal, H.S. Kanwar, S.C. Verma, Hukum Chand and Abhay Sharma. 2018. Impact of Climate Variability on Seed Yield of Onion in Mid Hills of Himachal Pradesh, India. Int.J.Curr.Microbiol.App.Sci. 7(02): 273-283. doi: https://doi.org/10.20546/ijcmas.2018.702.036 